\title{
Alzheimer's Presenilin Mutation Sensitizes Neural Cells to Apoptosis Induced by Trophic Factor Withdrawal and Amyloid $\beta$-Peptide: Involvement of Calcium and Oxyradicals
}

\author{
Qing Guo, ${ }^{1}$ Bryce L. Sopher, ${ }^{2}$ Katsutoshi Furukawa, ${ }^{1}$ Dao G. Pham, ${ }^{2}$ Nic Robinson, ${ }^{1}$ George M. Martin, ${ }^{2}$ and \\ Mark P. Mattson 1 \\ 1Sanders-Brown Research Center on Aging and Department of Anatomy and Neurobiology, University of Kentucky, \\ Lexington, Kentucky 40536, and 2Department of Pathology, University of Washington, Seattle, Washington 98195-7470
}

\begin{abstract}
Most autosomal dominant inherited forms of early onset Alzheimer's disease (AD) are caused by mutations in the presenilin-1 (PS-1) gene on chromosome 14. PS-1 is an integral membrane protein with six to nine membrane-spanning domains and is expressed in neurons throughout the brain wherein it is localized mainly in endoplasmic reticulum (ER). The mechanism or mechanisms whereby PS-1 mutations promote neuron degeneration in $A D$ are unknown. Recent findings suggest links among deposition of amyloid $\beta$-peptide $(\mathrm{A} \beta)$, oxidative stress, disruption of ion homeostasis, and an apoptotic form of neuron death in AD. We now report that expression of the human PS-1 L286V mutation in PC12 cells increases their susceptibility to apoptosis induced by trophic factor withdrawal and $A \beta$. Increases in oxidative stress and intracellular calcium levels induced by the apoptotic stimuli were exacerbated
\end{abstract}

greatly in cells expressing the PS-1 mutation, as compared with control cell lines and lines overexpressing wild-type PS-1. The antiapoptotic gene product Bcl-2 prevented apoptosis after NGF withdrawal from differentiated PC12 cells expressing mutant PS-1. Elevations of $\left[\mathrm{Ca}^{2+}\right]_{i}$ in response to thapsigargin, an inhibitor of the ER $\mathrm{Ca}^{2+}$-ATPase, were increased in cells expressing mutant PS-1, and this adverse effect was abolished in cells expressing Bcl-2. Antioxidants and blockers of calcium influx and release from ER protected cells against the adverse consequences of the PS-1 mutation. By perturbing cellular calcium regulation and promoting oxidative stress, PS-1 mutations may sensitize neurons to apoptotic death in AD.

Key words: Alzheimer's disease; antioxidant; bcl-2; dantrolene; endoplasmic reticulum; fura-2; nerve growth factor
Alzheimer's disease (AD) is a progressive and always fatal neurodegenerative disorder characterized by the death of neurons in brain regions involved in learning and memory processes (for review, see Selkoe, 1989). Accumulations of insoluble fibrillar aggregates of a protein called amyloid $\beta$-peptide $(\mathrm{A} \beta)$ are implicated in the pathogenesis of $\mathrm{AD} . \mathrm{A} \beta$ is associated with degenerating neurons in $\mathrm{AD}$ brain, and mutations in the gene for the amyloid precursor protein (the source of $A \beta$ ) cause a small percentage of cases of inherited familial AD (for review, see Mullan and Crawford, 1993). Moreover, mice genetically engineered to produce mutated human amyloid precursor protein exhibit $\mathrm{A} \beta$ deposition and cognitive impairments (Games et al., 1995; Hsaio et al., 1996). A $\beta$ damages and kills cultured neurons by a mechanism involving oxidative stress and disruption of cellular calcium homeostasis (Mattson et al., 1992; Behl et al., 1994; Fukuyama et al., 1994; Goodman and Mattson, 1994; Mark et al., 1995, 1997a). Apoptosis is a form of "programmed" cell death characterized by plasma membrane phospholipid alterations, cell shrinkage, and nuclear DNA condensation and fragmentation (Bredesen, 1995; Thompson, 1995). A $\beta$ induces apoptosis in cultured neurons (Forloni et al., 1993; Loo et al., 1993), and studies

Received Feb. 12, 1997; revised March 20, 1997; accepted March 25, 1997.

This work was supported by Grants to M.P.M. from National Institutes of Health (NS30583 and AG10836) and the Alzheimer's Association, to G.M.M. from National Institutes of Health (AG10917), and to B.L.S. from the University of Washington Nathan Shock Center for Excellence in the Basic Biology of Aging. We thank J. Begley, S. Bose, R. Pelfrey, and J. Xie for technical assistance.

Correspondence should be addressed to Dr. Mark P. Mattson, 211 Sanders-Brown Building, University of Kentucky, Lexington, KY 40536-0230.

Copyright (C) 1997 Society for Neuroscience $0270-6474 / 97 / 174212-11 \$ 05.00 / 0$ of postmortem brain tissue suggest that neuronal apoptosis occurs in $\mathrm{AD}$ (Su et al., 1994; Smale et al., 1995). The molecular and cellular mechanisms that predispose neurons to apoptotic death in $\mathrm{AD}$ are unknown.

An important step toward elucidating the cause or causes of neuron degeneration in $\mathrm{AD}$ was made with the identification of the genes responsible for the majority of cases of autosomal dominant inherited forms of early onset AD. The genes, called presenilin-1 (PS-1; chromosome 14) and presenilin-2 (PS-2; chromosome 1), encode proteins predicted to be integral membrane proteins with six to nine membrane-spanning domains (LevyLahad et al., 1995; Rogaev et al., 1995; Sherrington et al., 1995; Doan et al., 1996; Li and Greenwald, 1996). Immunohistochemical analyses indicate that PS-1 is expressed in neurons throughout the brain (Cook et al., 1996; Cribbs et al., 1996; Elder et al., 1996); PS-1 has been localized to both degenerating (Murphy et al., 1996) and nondegenerating (Giannakopoulos et al., 1997) neurons in AD brain. In cultured cells PS-1 localizes to subcellular compartments and seems to be at particularly high levels in the endoplasmic reticulum (ER) (Kovacs et al., 1996; Walter et al., 1996). PS-1 can be processed endoproteolytically (Thinakaran et al., 1996), although the significance of such processing is unknown. Because PS-1 mutations account for the majority of cases of inherited early onset forms of $\mathrm{AD}$, understanding the normal functions of PS-1 and how PS-1 mutations promote neuron degeneration are central issues in the $\mathrm{AD}$ field. We report that expression of a human PS-1 mutation in PC12 cells increases their vulnerability to apoptosis induced by trophic factor withdrawal and $\mathrm{A} \beta$. The mechanism whereby mutant PS- 1 promotes apopto- 
sis seems to involve disruption of calcium homeostasis and increased oxidative stress.

\section{MATERIALS AND METHODS}

Expression of wild-type and mutant PS-1 in PC12 cells. Rat pheochromocytoma (PC12) cells (Black and Greene, 1982) were maintained at $37^{\circ} \mathrm{C}$ (5\% $\mathrm{CO}_{2}$ atmosphere) in RPMI-1640 medium supplemented $10 \%$ with heat-inactivated horse serum and $5 \%$ with heat-inactivated fetal bovine serum. A full-length human PS- 1 cDNA and a PS- 1 cDNA containing the L286V mutation were cloned into either the expression vector pTRE in the Tet-off expression system (Clontech, Cambridge, UK) or pRc/CMV to produce pTRE-PS1 and pTRE-PS1L286V or pCMV-PS1 and pCMVPS1L286V, where, in both cases, the expression of PS-1 and PS-1 L286V cDNAs is under the control of CMV promoter. PC12 cells were transfected with Lipofectamine (Life Technologies, Gaithersburg, MD). Stable expression of PS-1 L286V in PC12 cells with the $\mathrm{pRc} / \mathrm{CMV}$ vector did not affect cell viability significantly during the G418 selection procedure. Double-stable PC12 cell lines in which PS-1 and PS-1 L286V expression could be suppressed or induced were established by first generating stable lines expressing the Tet-off system (cells were selected for 4 weeks in the presence of $0.8 \mathrm{mg} / \mathrm{ml}$ of G418). G418-resistant clones were isolated and cotransfected with the response plasmids pTRE-PS1 or pTRE-PS1L286V and pTK-Hyg. Cells were grown in selection medium containing 0.4 $\mathrm{mg} / \mathrm{ml}$ hygromycin, and stable clones were isolated after 4 weeks and screened for PS-1 expression in the presence or absence of $2 \mu \mathrm{g} / \mathrm{ml}$ Tet by Western blot or RT-PCR. Resulting double-stable cell lines that exhibited high levels of expression after removal of tetracycline were used for subsequent experiments. A PC12 cell line overexpressing Bcl-2 (a generous gift from D. Bredesen, The Burnaham Institute, La Jolla, CA Kane et al., 1993) was used to generate stable lines expressing the Tet-off system as described above. The latter lines then were cotransfected with the response plasmids pTRE-PS1 or pTRE-PS1L286V and pTK-Hyg, and stable lines exhibiting high levels of expression of wild-type and mutant PS-1 were used for experiments.

RT-PCR analysis was performed as described previously (Guo et al., 1996). Briefly, mRNA from the cultured cells was isolated and reversetranscribed via the reverse transcription system (Promega, Madison, WI) and the $3^{\prime}$ primer $5^{\prime}$-GCTTCCCATTCCTCACTGAA-3'. cDNA $(2.5 \mu \mathrm{l})$ was used as a template in a $50 \mu \mathrm{lPCR}$, using $15-40$ cycles of $94^{\circ} \mathrm{C}(1 \mathrm{~min})$, $60^{\circ} \mathrm{C}(2 \mathrm{~min})$, and $72^{\circ} \mathrm{C}(2 \mathrm{~min})$ with a final extension time of $10 \mathrm{~min}$ at $72^{\circ} \mathrm{C}$. Reaction mixtures were as recommended for $\mathrm{Taq}$ polymerase (Perkin-Elmer Cetus, Oak Brook, IL), except that Taq was added after the mixtures were heated to $95^{\circ} \mathrm{C}$ for $7 \mathrm{~min}$. The $3^{\prime}$ primer used was the oligonucleotide used to prime the cDNA synthesis; the $5^{\prime}$ primer was $5^{\prime}$ GTGGCTGTTTTGTGTCCGAA-3'. The PCR products were resolved and visualized by electrophoresis in $3 \%$ agarose gel stained with ethidium bromide. Because the Leu to Val mutation at codon 286 creates a PvuII site, the wild-type RT-PCR product could not be cut by $P v u \mathrm{II}$ and generated a single 251-bp fragment, whereas the mutation resulted in $P v u$ II cleavage of the product into 79 and 172 bp fragments.

Experimental treatments. Cells were differentiated to a neuron-like phenotype by incubation in medium with reduced serum concentration ( $2 \%$ fetal bovine serum) and containing $50 \mathrm{ng} / \mathrm{ml}$ nerve growth factor (NGF) (Black et al., 1982). Immediately before experimental treatment the medium was replaced with Locke's solution containing (in $\mathrm{mM}$ ): $\mathrm{NaCl}$ 154, $\mathrm{KCl}$ 5.6, $\mathrm{CaCl}_{2}$ 2.3, $\mathrm{MgCl}_{2}$ 1.0, $\mathrm{NaHCO}_{3}$ 3.6, glucose 5, and HEPES 5 , pH 7.2. Serum withdrawal from undifferentiated PC12 cells and NGF withdrawal from differentiated PC12 cells were accomplished by repeated washing of cells with Locke's solution. Synthetic A $\beta 25-35$ was purchased from Bachem (Torrence, CA), and stocks were prepared at a concentration of $1 \mathrm{~mm}$ in water and allowed to incubate overnight at $37^{\circ} \mathrm{C}$ before addition to cultures. Nifedipine, sodium dantrolene, thapsigargin, vitamin E, and propyl gallate were purchased from Sigma (St. Louis, MO) and prepared as $500 \times$ stocks in ethanol.

Generation of PS-1 antibodies and Western blot analysis. Affinity-purified polyclonal antibody was isolated from serum of rabbits injected with a synthetic peptide with a sequence ( $\mathrm{NH}_{2}$-NDDGGFSEEWEAQRD$\mathrm{COOH}$ ) corresponding to amino acids $331-345$ of the loop region of human PS-1. Preliminary studies showed that this antibody recognizes both wild-type and PS-1 L286V. For Western blot analysis solubilized cell proteins were separated by electrophoresis in a $12 \%$ polyacrylamide gel, transferred to a nitrocellulose sheet, and immunoreacted with PS-1 antibody (1:100). The nitrocellulose sheet was processed further with HRP-conjugated anti-mouse secondary antibody and a chemiluminescence detection method (Amersham, Arlington Heights, IL).
Analyses of cell death and apoptosis. Quantification of LDH levels in culture medium was done as described previously (Bruce et al., 1996). Levels of cellular 3-(4,5-dimethylthiazol-2-yl)-2,5-diphenyltetrazolium bromide (MTT) reduction, a measure of mitochondrial redox status and function (Shearman et al., 1994), were quantified as described previously (Mattson et al., 1995). Briefly, MTT solution (5 mg/ml PBS) was added to cultures (1:10, v:v; MTT solution/culture medium) and allowed to incubate for $3 \mathrm{hr}$. The cells were washed three times with Locke's solution and solubilized in dimethylsulfoxide; the absorbance in each culture well was quantified with a plate reader. Methods used to establish apoptotic cell death included Hoescht and propidium iodide staining of DNA and suppression of cell death by macromolecular synthesis inhibitors. For Hoescht and propidium iodide staining, cells were fixed in $4 \%$ paraformaldehyde, membranes were permeabilized with $0.2 \%$ Triton $\mathrm{X}-100$, and cells were stained with the fluorescent DNA-binding dyes Hoescht 33342 or propidium iodide, as described previously (Mark et al., 1995; Kruman et al., 1996). Hoescht-stained cultures were used to quantify the percentage of "apoptotic" cells; cells with condensed and fragmented DNA were considered apoptotic, whereas cells in which the DNA was distributed diffusely and uniformly throughout the nucleus were considered not apoptotic. Cells were visualized under epifluorescence illumination (340 $\mathrm{nm}$ excitation and $510 \mathrm{~nm}$ barrier filter) with a $40 \times$ oil immersion objective. Cells were counted in four random $40 \times$ fields per culture; counts were made without knowledge of cell type or treatment history. Images of propidium iodide-stained cells were acquired with a confocal laser scanning microscope (488 $\mathrm{nm}$ excitation and $510 \mathrm{~nm}$ barrier filter; Molecular Dynamics, Sunnyvale, CA) with a $60 \times$ oil immersion objective. Measurements of intracellular peroxide and calcium levels. Peroxide levels were measured by using the dye 2,7-dichlorofluorescein diacetate (DCF) as described previously (Goodman and Mattson, 1994; Mattson et al., 1995). Ratiometric imaging of the calcium indicator dye fura-2 was performed as described previously (Mattson et al., 1992, 1993a). For measurements of DCF fluorescence and $\left[\mathrm{Ca}^{2+}\right]_{\mathrm{i}}$ after exposure to $\mathrm{A} \beta$, cells were loaded with DCF or fura- 2 and maintained in the presence of $\mathrm{A} \beta$ during imaging.

\section{RESULTS}

\section{PC12 cells expressing mutant PS-1 exhibit increased vulnerability to apoptosis induced by serum withdrawal and amyloid $\beta$-peptide}

Rat neural (PC12) cells were stably transfected with a DNA construct encoding PS-1 containing the 286 leu-val mutation (L286V), and additional lines were transfected with wild-type PS-1 or vector alone. RT-PCR analysis showed that PS-1 and PS-1 L286V mRNAs were expressed at variable levels in each of the transfected cell lines isolated (data not shown) (cf. Guo et al., 1996). Levels of PS-1 expression were established in Western blot analyses (Fig. 1); clonal lines expressing moderately high levels of wild-type PS-1 $(n=3)$ or PS1L286V $(n=3)$, one vectortransfected line, and the untransfected parent cell line were chosen for use in the present study. Densitometric analyses of Western blots showed that the levels of expression of wild-type and mutant PS-1 in the clones chosen were very similar and were at least five times greater than the background level of endogenous PS-1 (Fig. 1B). Under the normal culture maintenance conditions, overexpression of wild-type or mutant PS-1 at the levels of the lines used in the present study did not seem to affect cell survival or growth.

To determine whether the expression of PS-1 L286V affected cell death after trophic factor withdrawal, we deprived various lines of undifferentiated PC12 cells of serum, an insult previously shown to induce apoptosis (Bastitatou and Greene, 1991; Rukenstein et al., 1991). In untransfected and vector-transfected PC12 cells there was a progressive appearance of cells with apoptotic nuclei that occurred between 12 and $48 \mathrm{hr}$ after serum withdrawal (Fig. 2A). In PC12 cells expressing PS-1 L286V there was a dramatic increase in the numbers of apoptotic cells present at 12 , 
A

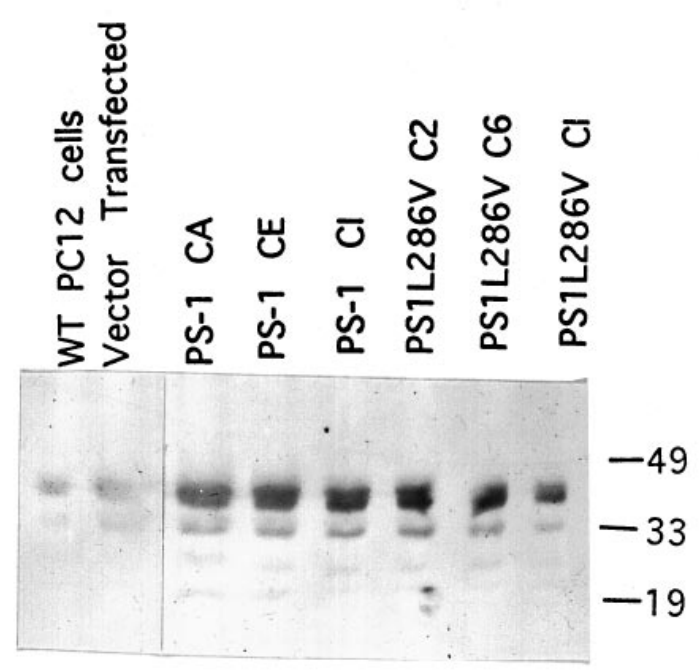

B

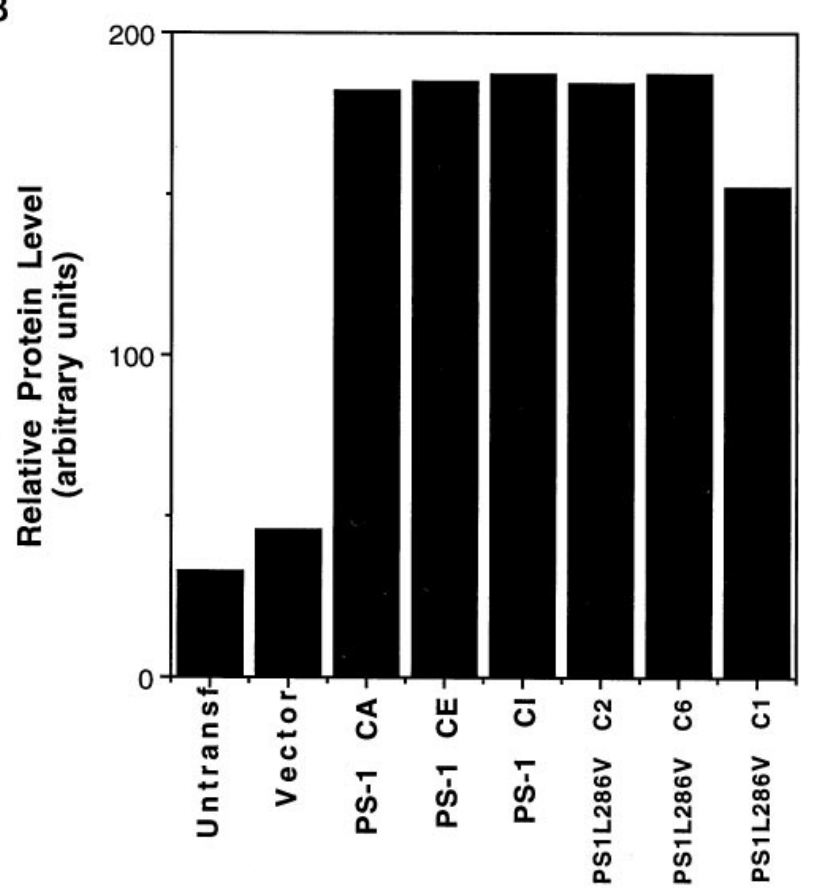

Figure 1. Expression of wild-type and mutant PS-1 in PC12 cells. A, Western blot showing PS-1 protein in untransfected and vectortransfected PC12 cells and in three different lines of cells expressing wild-type (PS-1) and mutant (PS1L286V) PS-1. Equivalent amounts of protein $(50 \mu \mathrm{g} /$ lane $)$ from cell homogenates of the indicated cell lines (untransfected cells, vector-transfected cells, PS-1, and PS1L286V) were separated by SDS-PAGE, transferred to nitrocellulose, and probed with PS-1 antibody. Similar to results of other investigators (Thinakaran et al., 1996), in addition to recognizing full-length PS-1 (46 kDa band), our anti-loop PS-1 antibody also recognized presumptive proteolytic products of PS-1 $\sim 32$ and $19 \mathrm{kDa}$. $B$, Densitometric analysis of relative levels of PS-1 protein in PC12 cell lines stably expressing wild-type (PS-1) and mutant (PS1L286V) PS-1. Note that basal PS-1 levels are relatively low in PC12 cells and that levels of expression of wild-type and mutant PS-1 were similar among the lines shown.

24, and $48 \mathrm{hr}$ after serum withdrawal (Fig. $2 A, C$ ). In another set of experiments cells were differentiated into a neuron-like phenotype by chronic exposure to NGF, and then the NGF was withdrawn. Apoptosis induced by NGF withdrawal in cell lines expressing mutant PS-1 was significantly greater than in untransfected cells, vector-transfected cells, and cells overexpressing wildtype PS-1 (Fig. 2B). NGF withdrawal induced apoptosis in $\sim 20 \%$ of cells in untransfected and vector-transfected cell lines and in $\sim 80 \%$ of the cells in lines expressing mutant PS-1. The level of apoptosis after NGF withdrawal in cells overexpressing wild-type PS-1 was somewhat higher than that in vector-transfected and untransfected lines, although the difference did not reach statistical significance (Fig. 2B).

Previous studies showed that $\mathrm{A} \beta$ can induce apoptosis in cultured primary neurons (Loo et al., 1993) and PC12 cells (Gschwind and Huber, 1995). Exposure of undifferentiated PC12 cells to $\mathrm{A} \beta$ for $24 \mathrm{hr}$ induced apoptotic nuclear changes, and the percentage of cells undergoing apoptosis was significantly greater in cells expressing PS-1 L286V than in untransfected cells, vectortransfected cells, and cells overexpressing wild-type PS-1 (Fig. $3 A$ ). Nuclear condensation and fragmentation induced by $\mathrm{A} \beta$ (Fig. $3 A$ ) and serum withdrawal (data not shown) were prevented by the protein synthesis inhibitor cycloheximide, consistent with an apoptotic mechanism of cell death. It was reported previously that $\mathrm{A} \beta$ causes a relatively rapid (minutes to hours) impairment of mitochondrial function as measured by MTT reduction that occurs very early in the apoptotic process (Shearman et al., 1994; Kruman et al., 1996). Exposure of PC12 cells to A $\beta$ resulted in a decrease in levels of MTT reduction in all cell lines examined, and the magnitude of the decrease in MTT reduction was significantly greater in each line expressing PS-1 L286V than in untransfected cells, cells transfected with empty vector, and lines overexpressing wild-type PS-1 (Fig. 3B).

\section{Proapoptotic action of PS-1 mutation involves disruption of calcium homeostasis and induction of oxidative stress}

To test the hypothesis that PS-1 mutations promote cell death by increasing oxidative stress, we determined whether antioxidants would protect cells against death induced by $\mathrm{A} \beta$ and measured levels of peroxides in the different cell lines after exposure to $A \beta$. When cultures were pretreated with the antioxidants propyl gallate or vitamin $\mathrm{E}$ before exposure to $\mathrm{A} \beta$, cell death $24 \mathrm{hr}$ later was reduced significantly, and the death-enhancing effect of $\mathrm{L} 286 \mathrm{~V}$ was prevented (Fig. 4A). In light of previous data implicating disruption of cellular calcium homeostasis in the mechanism of A $\beta$ cytotoxicity (Mattson et al., 1992, 1993a; Mark et al., 1995) and apoptosis (Takei and Endo, 1994; Ciutat et al., 1995), we determined whether cells expressing PS-1 L286V exhibit increased sensitivity to $\mathrm{A} \beta$-induced elevation of $\left[\mathrm{Ca}^{2+}\right]_{\mathrm{i}}$ and whether agents that suppress calcium influx would protect cells against the adverse effects of PS- $1 \mathrm{~L} 286 \mathrm{~V}$. A $\beta$ induced an increase in $\left[\mathrm{Ca}^{2+}\right]_{\mathrm{i}}$ during a $4 \mathrm{hr}$ exposure period; the elevation of $\left[\mathrm{Ca}^{2+}\right]_{\mathrm{i}}$ was significantly greater in cells expressing PS-1 L286V, as compared with control cell lines (Fig. $4 B$ ). A $\beta$ caused $\left[\mathrm{Ca}^{2+}\right]_{i}$ to increase to $150-170 \mathrm{~nm}$ in control cell lines and to $>300 \mathrm{nM}$ in L286V-expressing cells. Cell death induced by A $\beta$, and the deathenhancing effect of PS-1 L286V was attenuated significantly in cultures pretreated with nifedipine, a blocker of L-type voltagedependent calcium channels (Fig. $4 A$ ). Dantrolene, an inhibitor of calcium release from ER stores, also in large part prevented $\mathrm{A} \beta$-induced cell death in cells expressing L286V, suggesting a role for altered calcium release in the proapoptotic action of PS-1 
A

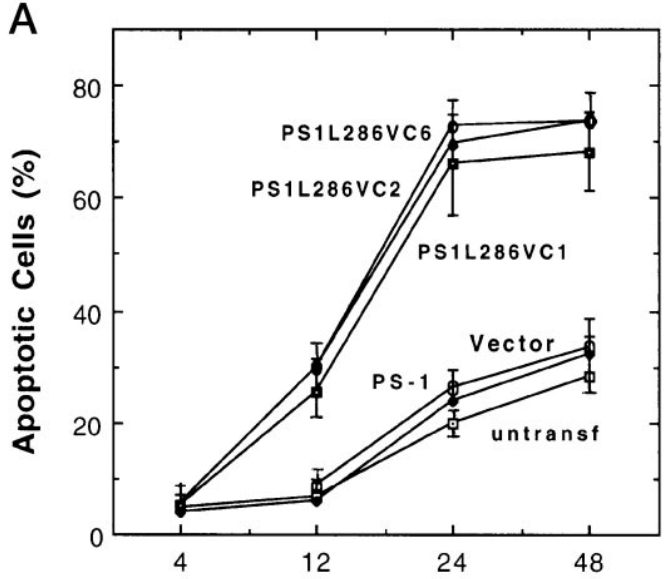

Time Following Serum Withdrawal (hr)
B

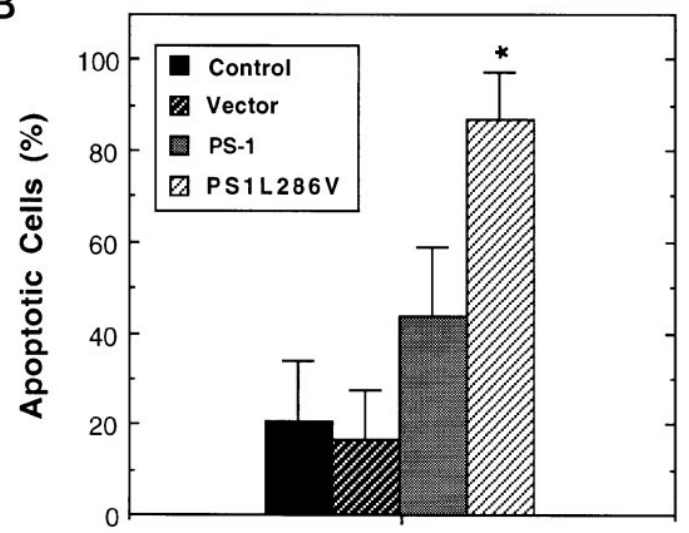

C
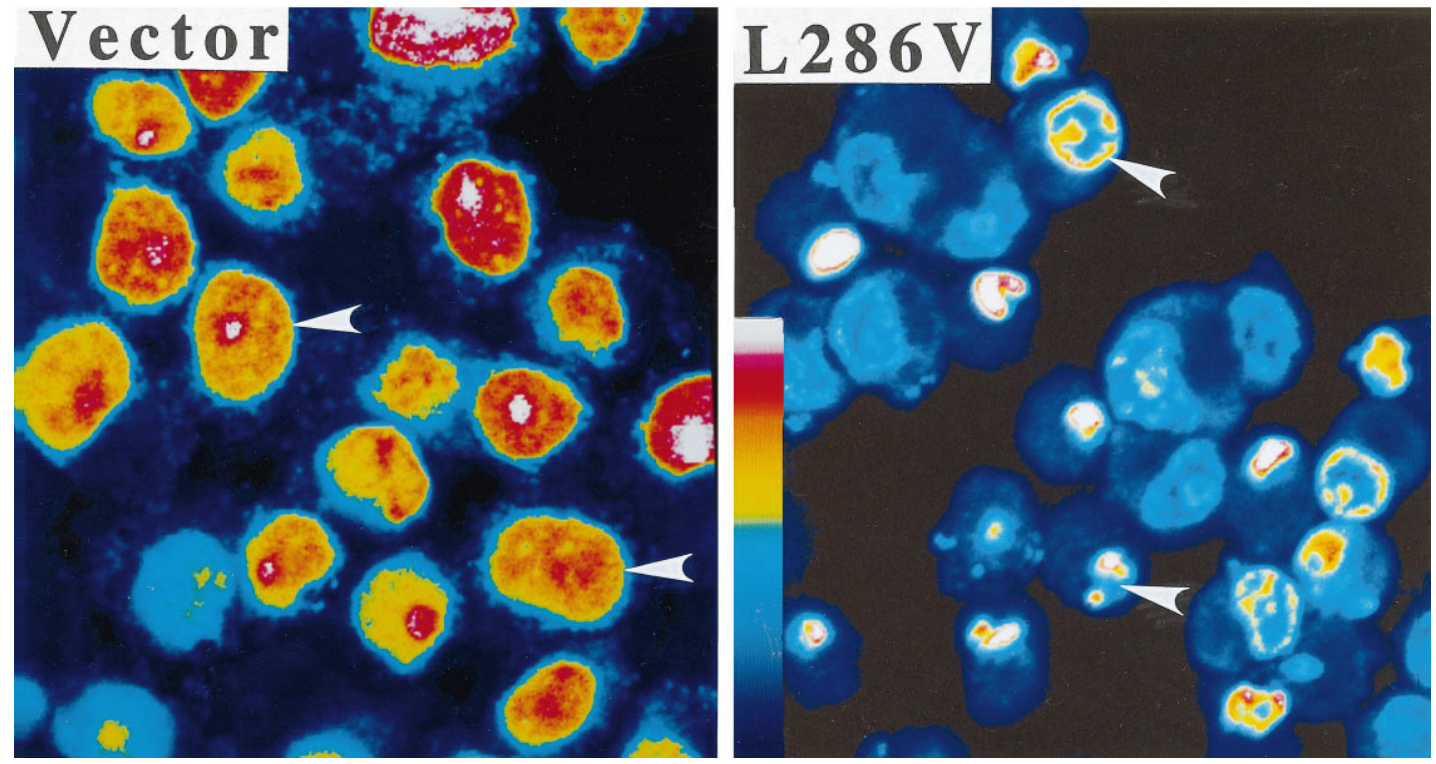

Figure 2. PC12 cells expressing PS-1 L286V mutation exhibit increased vulnerability to apoptosis induced by trophic factor withdrawal. $A$, The percentages of cells exhibiting DNA condensation and fragmentation (apoptotic cells) were determined in Hoescht-stained cultures at the indicated times after serum withdrawal from undifferentiated PC12 cell lines: untransf, untransfected cells; Vector, cells transfected with empty vector; PS-1, cells transfected with wild-type PS-1 (pooled data from three different lines; C1, C2, and C6); and three different lines expressing mutant PS-1 (PS1L286V). Values represent the mean and SD of determinations made in four separate cultures ( 200 cells counted/culture). Values for each of the three cell lines expressing L286V were greater than corresponding values for untransfected cultures and cultures transfected with vector or wild-type PS-1 (12 hr time point, $p<0.05 ; 24$ and $48 \mathrm{hr}$ time points, $p<0.001)$; ANOVA with Scheffé's post hoc tests. $B$, Control untransfected PC12 cells $(C o n t r o l)$ and PC12 cells transfected with empty vector (Vector), wild-type PS-1 (PS-1), or mutant PS-1 (PS1L286V) were differentiated in the presence of NGF (data pooled from analyses on all three lines expressing wild-type PS-1 and all three lines expressing PS-1 L286V; compare with Fig. 1). NGF was withdrawn, and 48 hr later the percentages of apoptotic cells in each culture were determined. Values represent the mean and SD of determinations made in four separate cultures. ${ }^{*} p<0.01$ compared with each of the other values; ANOVA with Scheffé's post hoc tests. $C$, Confocal images of propidium iodide fluorescence in vector-transfected and L286V-transfected PC12 cells $24 \mathrm{hr}$ after serum withdrawal. Fluorescence intensity is depicted in pseudocolor according to the color scale bar. Note that DNA is distributed diffusely throughout the nuclei of most vector-transfected cells, whereas DNA is fragmented to varying extents in most cells expressing PS-1 L286V (arrowheads).

L286V (Fig. 4A). Nifedipine and dantrolene also afforded partial protection against the adverse effects of mutant PS- 1 on $\left[\mathrm{Ca}^{2+}\right]_{\mathrm{i}}$ (Fig. $4 B$ ) and cellular peroxide levels (Fig. $4 C$ ). As expected from previous studies (Behl et al., 1994; Goodman and Mattson, 1994), exposure of PC12 cells to $\mathrm{A} \beta$ for $4 \mathrm{hr}$ caused an increase in cellular peroxide levels; the increase was significantly greater in cells expressing PS-1 L286V than in control cell lines (Fig. 4C). Pretreatment with either propyl gallate or vitamin $\mathrm{E}$ in large part abolished the $\mathrm{A} \beta$-induced increase in peroxide levels (Fig. $4 C$ ).
Collectively, these data indicated that mutant PS-1 may sensitize neural cells to apoptosis by perturbing calcium homeostasis and free radical metabolism.

\section{Apoptosis in differentiated PC12 cells induced by NGF withdrawal is enhanced by mutant PS-1}

The experiments described above used PC12 cell lines stably expressing high levels of wild-type or mutant PS-1, a situation that 
A
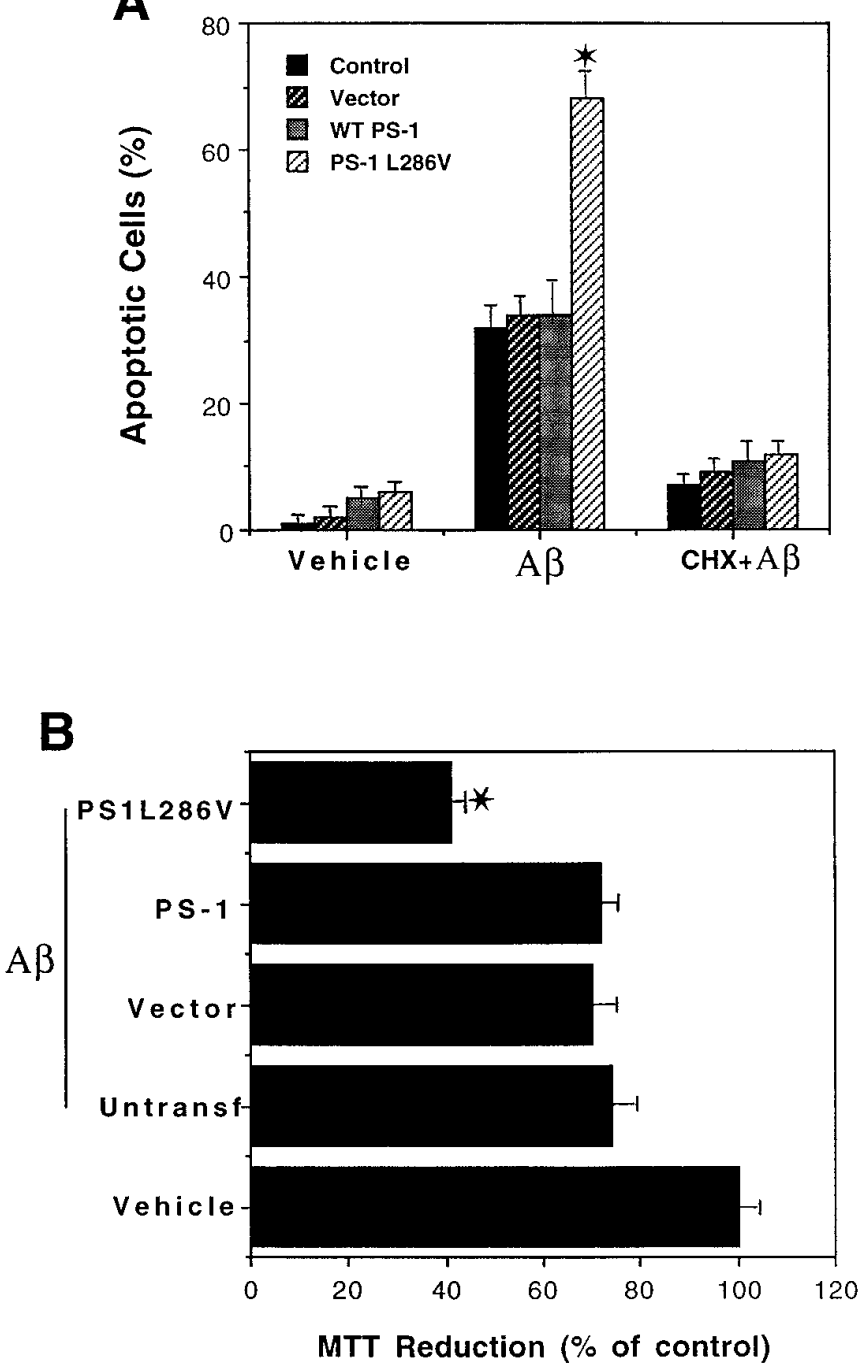

Figure 3. Mutant PS-1 increases PC12 cell vulnerability to apoptosis and mitochondrial dysfunction induced by amyloid $\beta$-peptide. $A$, The indicated cell lines were exposed to vehicle (Vehicle), $50 \mu \mathrm{M} \mathrm{A} \beta(A \beta)$, or $10 \mu \mathrm{M}$ cycloheximide plus $50 \mu \mathrm{M} \mathrm{A} \beta(C H X+A \beta)$ for $24 \mathrm{hr}$. Then cells were stained with Hoescht dye, and the percentages of cells exhibiting DNA condensation and fragmentation were determined. Values represent the mean and SD of determinations made in four separate cultures (data pooled from analyses on all three lines expressing wild-type PS-1 and all three lines expressing PS-1 L286V; compare with Fig. 1). For all cell lines the values for cells exposed to $A \beta$ were significantly greater than values for vehicle or $\mathrm{CHX}$ plus $\mathrm{A} \beta$-treated cell lines $(p<0.01) .{ }^{*} p<0.01$ compared with each of the other cell lines exposed to A $\beta$; ANOVA with Scheffé's post hoc tests. $B$, Parallel cultures of untransfected control cells (Untransf), vector-transfected cells (Vector), three lines of cells transfected with wild-type PS-1 (PS-1; pooled data), and three lines of mutant PS-1 cells (PS1L286V; pooled data) were exposed for $4 \mathrm{hr}$ to $50 \mu \mathrm{M} \mathrm{A} \beta$, and relative levels of MTT reduction (a measure of mitochondrial function) were quantified. Values are the mean and SD of determinations made in four separate cultures and are expressed as a percentage of vehicle-treated control (vector-transfected) cells (data pooled from analyses on all three lines expressing wild-type PS-1 and all three lines expressing PS-1 L286V; compare with Fig. 1). There were no differences in basal levels of MTT reduction among the various control, wild-type PS-1-expressing, and mutant PS-1-expressing lines (data not shown). ${ }^{*} p<0.01$ compared with corresponding values for untransfected, vector-transfected, and WT PS-1-transfected lines exposed to A $\beta$; ANOVA with Scheffé's post hoc tests. could perturb metabolic pathways nonspecifically in the cells. Moreover, because wild-type and mutant PS-1 were expressed throughout the period of NGF-induced cell differentiation, we could not rule out the possibility that mutant PS-1 affects the differentiation process. To examine further the proapoptotic actions of PS-1 mutations, we therefore established PC12 lines expressing wild-type and mutant PS-1 under the control of a tetracycline-suppressible (Tet-off) promoter. For these experiments cells were maintained in the presence of tetracycline during the period of differentiation with NGF. After differentiation and $48 \mathrm{hr}$ before NGF withdrawal, tetracycline concentration was reduced to induce PS-1 wild-type or mutant expression. As expected, levels of PS-1 expression increased with decreasing concentrations of tetracycline in the culture medium (Fig. $5 A$ ); subsequent experiments were performed in cultures induced to express wild-type or mutant PS-1 at comparable levels (Fig. $5 B$ ). Withdrawal of NGF from differentiated untransfected, vector-transfected, and Tet-off-transfected PC12 cells resulted in apoptosis of $\sim 40 \%$ of the cells during a $48 \mathrm{hr}$ period (Fig. $6 A)$. In contrast, apoptosis did not occur after NGF withdrawal in PC12 cells expressing Bcl-2. NGF withdrawal-induced apoptosis was enhanced significantly in PC12 cells expressing mutant PS-1 L286V (Fig. 6C), as compared with cells expressing wild-type PS-1 (Fig. 6B). Cells expressing PS-1 L286V also exhibited a modest increase in basal levels of apoptosis in the presence of NGF. PC12 cells expressing Bcl-2 in combination with wild-type or mutant PS-1 were completely resistant to apoptosis induced by NGF withdrawal (Fig. 6C). Collectively, these data indicate that mutant PS-1 possesses an adverse property not present in wild-type PS-1 that sensitizes neurons to apoptosis.

\section{Enhanced oxidative stress after NGF withdrawal and perturbed calcium homeostasis in differentiated PC12 cells expressing mutant PS-1}

Withdrawal of NGF from differentiated untransfected and vectortransfected PC12 cells resulted in an increase in levels of cellular peroxides that occurred within $3 \mathrm{hr}$ (Fig. 7A). An increase in cellular peroxides also occurred after NGF withdrawal from PC12 cells expressing Bcl-2, suggesting that the antiapoptotic action of Bcl-2 occurred downstream of the oxidative stress (cf. Greenlund et al., 1995). NGF withdrawal-induced peroxide accumulation was enhanced greatly in PC12 cells expressing the mutant PS-1 L286V, as compared with cells expressing wild-type PS-1 (Fig. 7B). Basal levels of peroxides in cells expressing PS-1 L286V were somewhat higher than in control cells, although the difference did not reach statistical significance. PC12 cells expressing Bcl-2 in combination with mutant PS-1 exhibited peroxide levels after NGF withdrawal that were lower than in cells lacking Bcl-2, but the difference did not reach statistical significance (Fig. $7 C$ ).

PS-1 is localized to the ER, and a recent study showed that PC12 cells expressing mutant PS-1 exhibit altered ER calcium regulation (Guo et al., 1996). We therefore examined calcium responses to thapsigargin, an inhibitor of the $\mathrm{ER} \mathrm{Ca}^{2+}-\mathrm{ATPase}$ in differentiated PC12 cells expressing wild-type or mutant PS-1, with or without Bcl-2. Rest $\left[\mathrm{Ca}^{2+}\right]_{\mathrm{i}}$ was $\sim 60 \mathrm{nM}$ in control cells and was elevated to $80-110 \mathrm{~nm}$ in cells expressing PS-1 L286V (Fig. 8). In PC12 cells not expressing PS-1, thapsigargin caused an increase in $\left[\mathrm{Ca}^{2+}\right]_{\mathrm{i}}$ to $160-180 \mathrm{nM}$, and the response was attenuated by $\sim 50 \%$ in cells expressing Bcl-2 (Fig. 8A). PC12 cells expressing PS-1 L286V exhibited a markedly en- 

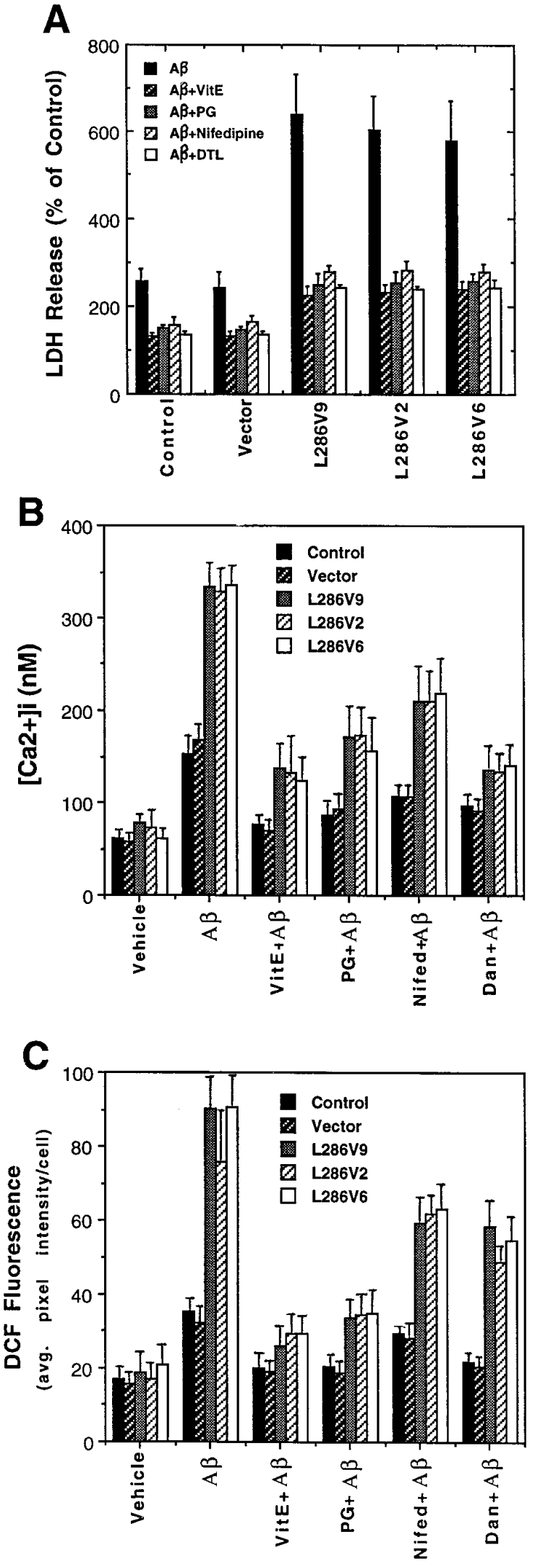

Figure 4. PC12 cells expressing PS-1 L286V mutation exhibit increased levels of oxidative stress and intracellular calcium after exposure to $\mathrm{A} \beta$ : attenuation by antioxidants and blockers of calcium influx and release from intracellular stores. $A$, Cultures were pretreated for $24 \mathrm{hr}$ with $50 \mu \mathrm{M}$ vitamin $\mathrm{E}(\mathrm{Vit} E)$ or for $2 \mathrm{hr}$ with $5 \mu \mathrm{M}$ propyl gallate $(P G), 1 \mu \mathrm{M}$ nifedipine
A
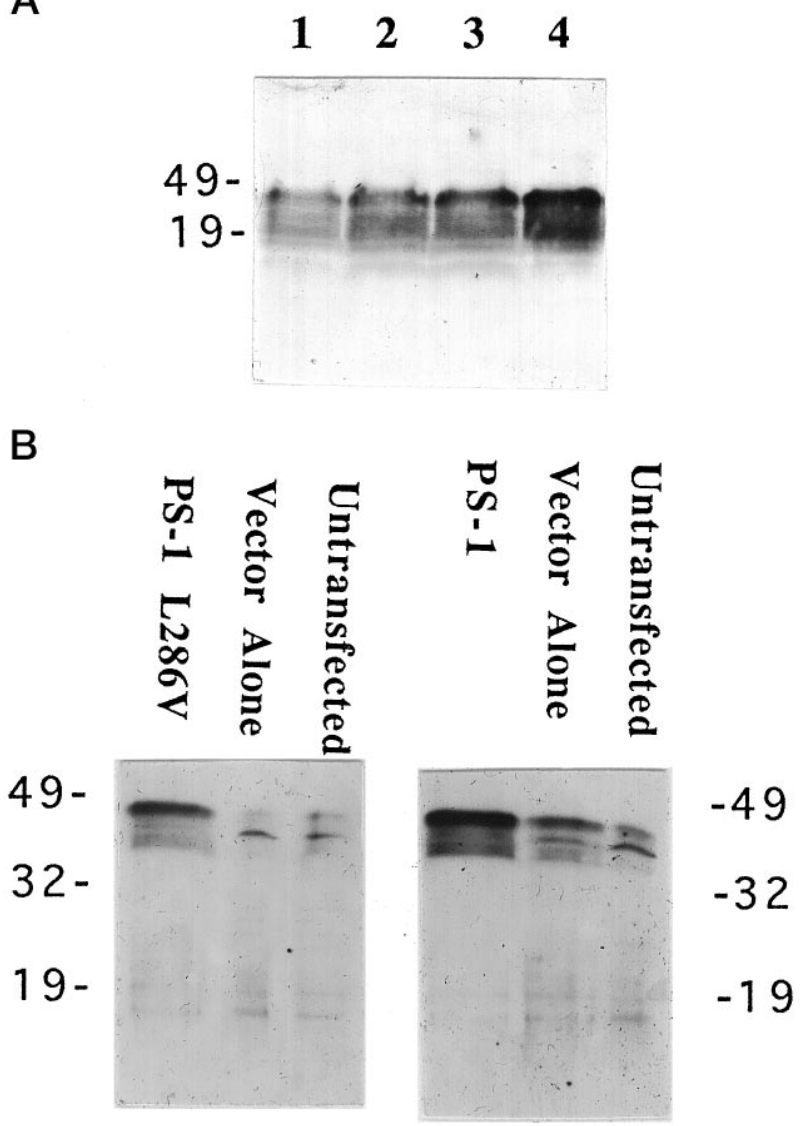

Figure 5. Controlled expression of PS-1 in PC12 cells with the use of a tetracyline-responsive transactivator. $A, \mathrm{~A}$ PC12 cell line expressing the "Tet-off" construct was stably transfected with a pTRE-derived plasmid expressing PS-1 L286V gene. Cells were incubated for $48 \mathrm{hr}$ in the presence of 2.0, 0.004, 0.002, and $0 \mu \mathrm{g} / \mathrm{ml}$ tetracycline (lanes $1-4$, respectively). Cell proteins were separated by SDS-PAGE (100 $\mu \mathrm{g} /$ lane $)$, transferred to a nitrocellulose sheet, and immunoreacted with PS-1 antibody. Note that, as the concentration of tetracycline was decreased, the levels of mutant PS-1 expression increased. $B$, Western blot showing that in the absence of tetracycline a double-stable PS-1 L286V cell line (C1) and a double-stable PS-1 cell line (C3) show significantly higher levels of PS-1 expression than do vector-transfected or untransfected cell lines.

(Nifedipine), or $1 \mu \mathrm{M}$ dantrolene (DTL). Then cultures were exposed to $50 \mu \mathrm{M}$ $\mathrm{A} \beta$ for $24 \mathrm{hr}$, and the medium was removed for LDH assay (cells exposed to $\mathrm{A} \beta$ first undergo apoptosis, followed by secondary necrosis, the latter being detected by LDH release assay). Values are expressed as a percentage of the maximal LDH release (mean and SD of 6-8 cultures); maximal LDH release was determined in parallel cultures (of each cell line) subjected to freezethaw. Values for each of the A $\beta$-treated cell lines expressing PS-1 L286V were significantly greater than each of the values for control (untransfected) and vector-transfected cell lines $(p<0.01)$ and for each of the values in PS-1 L286V cultures pretreated with vitamin E, propyl gallate, nifedipine, or dantrolene ( $p<0.01$ in each case); ANOVA with Scheffé's post hoc tests. $B$, $C$, Cultures were pretreated with antioxidants or $\mathrm{Ca}^{2+}$ flux blockers as described for $A$ and then exposed to vehicle or A $\beta$ for $4 \mathrm{hr}$. Then the relative $\left[\mathrm{Ca}^{2+}\right]_{\mathrm{i}}$ (fura-2 imaging) $(B)$ and levels of peroxides (DCF Fluorescence) $(C)$ in individual cells were quantified. Values are the mean and SD of determinations made in three to four cultures (15-25 cells for $\left[\mathrm{Ca}^{2+}\right]_{\mathrm{i}}$ measurements and 40-60 cells/culture for DCF measurements). Values for each of the $\mathrm{A} \beta$-treated cell lines expressing L286V were significantly greater than each of the values in the vehicle-treated cultures $(p<0.01)$, each of the values in the cultures pretreated with vitamin $\mathrm{E}$ or propyl gallate $(p<0.01)$, and each of the values for L286V cells in the cultures pretreated with nifedipine or dantrolene $(p<0.05)$; ANOVA with Scheffé's post hoc tests. 

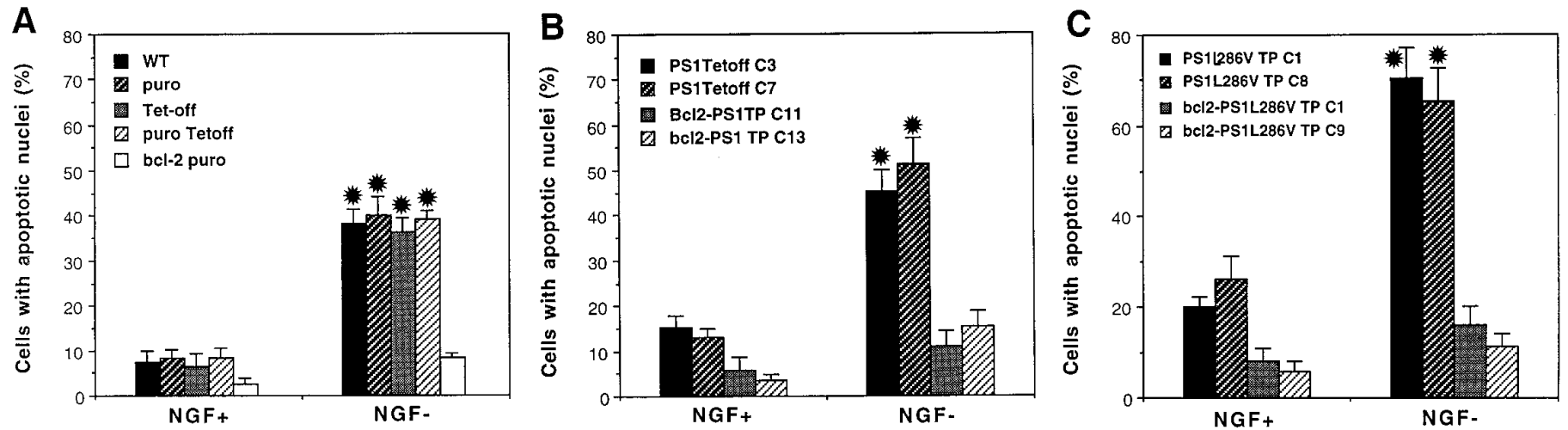

Figure 6. Mutant PS-1 increases the vulnerability of differentiated PC12 cells to NGF withdrawal-induced apoptosis. Cultures of differentiated PC12 cells were incubated for $48 \mathrm{hr}$ in serum-free medium containing or lacking NGF, and the percentage of cells exhibiting nuclear condensation and fragmentation was quantified. Values are the mean and SEM of determinations made in at least four separate cultures. $A$, Analyses in various control PC12 cell lines: $W T$, untransfected wild-type cells; puro, vector-transfected cells (pBabe-puro vector used for Bcl-2 expression); Tet-off, cells transfected with the Tet-off plasmid; puro Tet-off, cells doubly transfected with pBabe-puro vector and Tet-off plasmid; bcl-2 puro, cells expressing Bcl-2. Note that NGF withdrawal induced a similar level of apoptosis in all control lines, whereas cells expressing Bcl-2 were resistant to NGF withdrawal-induced apoptosis. * $p<0.01$ compared with corresponding values for $\mathrm{NGF}^{+}$cultures and the value for Bcl-2 $\mathrm{NGF}^{-}$cells. $B, \mathrm{Bcl}-2$ protects PC12 cells overexpressing wild-type PS-1 against NGF withdrawal-induced apoptosis. Two lines of control cells expressing wild-type PS-1 (C3 and $C 7$ ) and two different lines of cells expressing both Bcl-2 and PS-1 (C11 and C13) were analyzed. * $p<0.01$ compared with corresponding values for NGF ${ }^{+}$cells and compared with the value for the $\mathrm{NGF}^{-}$line expressing Bcl-2. C, Mutant PS-1 enhances vulnerability of PC12 cells to apoptosis induced by NGF withdrawal: protection by Bcl-2. Two lines of control cells expressing PS-1 L286V and two lines of cells expressing both Bcl-2 and PS-1 L286V were analyzed. * $p<0.05$ compared with corresponding values for each line expressing wild-type PS-1 $(B), p<0.01$ compared with corresponding values for cells maintained in the presence of NGF, and $p<$ 0.01 compared with $\mathrm{NGF}^{-}$lines coexpressing Bcl-2; ANOVA with Scheffé's post hoc tests for pair-wise comparisons.
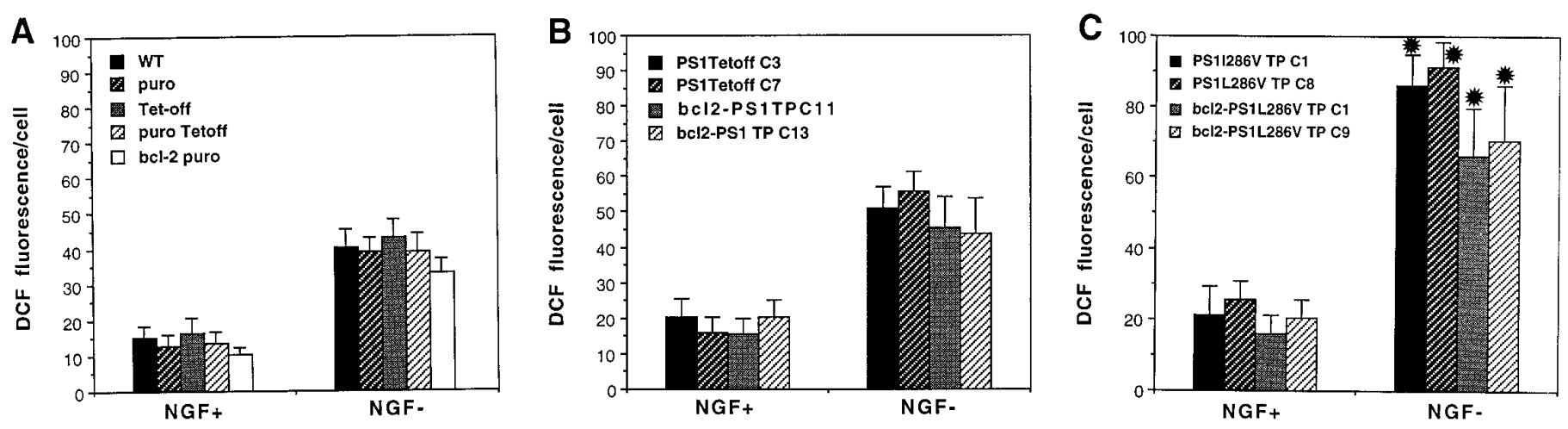

Figure 7. Oxidative stress induced by NGF withdrawal is enhanced in PC12 cells expressing mutant PS-1. Cultures of differentiated PC12 cells were incubated for $3 \mathrm{hr}$ in serum-free medium containing or lacking NGF, and levels of cellular peroxides were quantified by confocal laser scanning microscope image analysis of DCF fluorescence. Values are the mean and SEM of determinations made in at least four separate cultures. $A$, Analyses in various control PC12 cell lines: WT, untransfected wild-type cells; puro, vector-transfected cells; Tet-off, cells transfected with the Tet-off plasmid; puro Tet-off, cells doubly transfected with empty vector and Tet-off plasmid; bcl-2 puro, cells expressing Bcl-2. Note that NGF withdrawal induced a similar level of peroxide accumulation in all control lines and in cells overexpressing $\mathrm{Bcl}-2$. Each value for $\mathrm{NGF}^{-}$cultures was significantly greater than the corresponding value for $\mathrm{NGF}^{+}$cells $(p<0.01) . B, \mathrm{Bcl}-2$ does not prevent NGF withdrawal-induced accumulation of peroxides in PC12 cells overexpressing wild-type PS-1. Two lines of control cells expressing wild-type PS-1 (C3 and $C 7)$ and two different lines of cells expressing both Bcl-2 and PS-1 (C11 and C13) were analyzed. Each value for NGF- cultures was significantly greater than the corresponding value for NGF ${ }^{+}$cells $(p<0.01)$. $C$, Mutant PS-1 enhances accumulation of peroxides in PC12 cells deprived of NGF. Two lines of control cells expressing PS-1 L286V and two lines of cells expressing both Bcl-2 and PS-1 L286V were analyzed. ${ }^{*} p<0.05$ compared with corresponding values for each line expressing wild-type PS-1 (B) and $p<0.01$ compared with corresponding values for cells maintained in the presence of NGF; ANOVA with Scheffé's post hoc tests for pair-wise comparisons).

hanced peak $\left[\mathrm{Ca}^{2+}\right]_{\mathrm{i}}$ response to thapsigargin, with levels rising to $\sim 400 \mathrm{~nm}$ (Fig. $8 \mathrm{C}$ ). The enhanced $\left[\mathrm{Ca}^{2+}\right]_{\mathrm{i}}$ response to thapsigargin was abolished completely in PC12 cells expressing Bcl-2 (Fig. 8C). Taken together with the data above showing that dantrolene protects PC12 cells against the proapoptotic actions of PS-1 L286V, these findings suggest that altered ER calcium regulation is involved mechanistically in the apoptotic action of mutant PS-1.

\section{DISCUSSION}

Previous studies showed that both A $\beta$ (Rabizadeh et al., 1994; Gschwind and Huber, 1995) and trophic factor withdrawal (Bastitatou and Greene, 1991; Rukenstein et al., 1991) induce apoptosis in PC12 cells. Similarly, A $\beta$ (Forloni et al., 1993; Loo et al., 1993) and trophic factor deprivation (Prehn et al., 1994) induce apoptosis in neurons in primary cultures established from brain regions (e.g., hippocampus, neocortex, and basal forebrain) that 

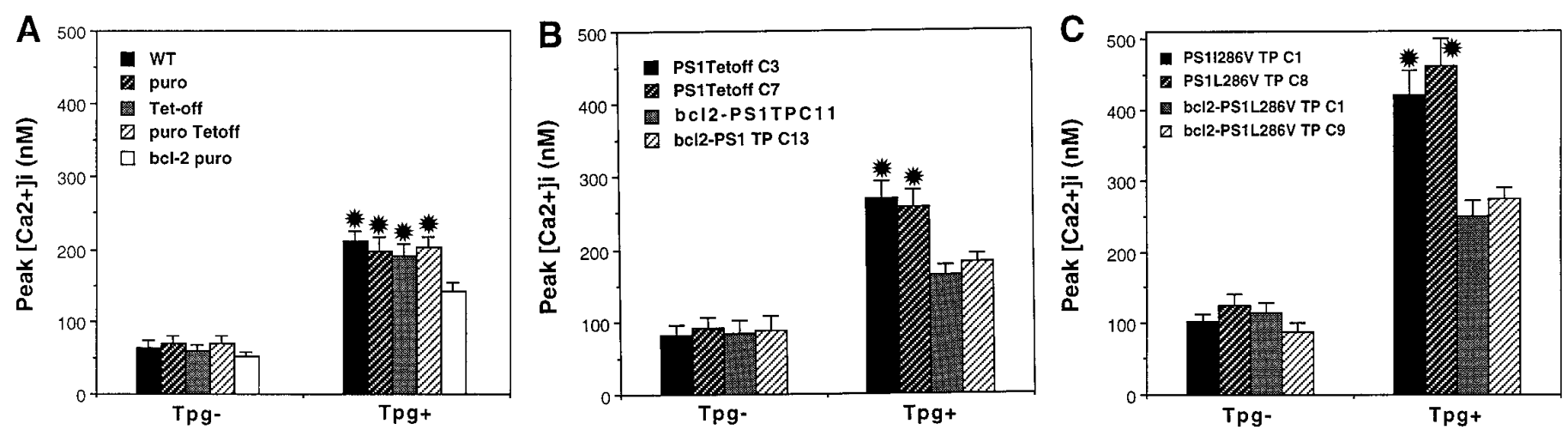

Figure 8. Elevations of $\left[\mathrm{Ca}^{2+}\right]_{\mathrm{i}}$ induced by thapsigargin are enhanced significantly in PC12 cells expressing mutant PS-1: attenuation by Bcl-2. PC12 cells were incubated in serum-free medium and basal $\left[\mathrm{Ca}^{2+}\right]_{\mathrm{i}}\left(\mathrm{Tpg}^{-}\right)$, and the peak $\left[\mathrm{Ca}^{2+}\right]_{\mathrm{i}}$ after exposure to $1 \mu \mathrm{M}$ thapsigargin $\left(\mathrm{Tpg}^{+}\right)$was quantified $(\mathrm{cf}$. Guo et al., 1996). Values are the mean and SEM of determinations made in at least four separate cultures (15-20 cells/culture). $A$, Analyses in various control PC12 cell lines: WT, untransfected wild-type cells; puro, vector-transfected cells (vector for Bcl-2-expressing line); Tet-off, cells transfected with the Tet-off plasmid; puro Tet-off, cells doubly transfected with pBabe-puro and Tet-off plasmid; $b c l-2$ puro, cells expressing Bcl-2. * $p<0.01$ compared with corresponding values for $\mathrm{Tpg}^{-}$cultures, and $p<0.05$ compared with the $\mathrm{Tpg}^{+}$value in cells expressing $\mathrm{Bcl}-2 . B$, The $\left[\mathrm{Ca}^{2+}\right]_{\mathrm{i}}$ response to thapsigargin in cells expressing wild-type PS-1 is attenuated in cells coexpressing Bcl-2. ${ }^{*} p<0.01$ compared with corresponding values for Tpg ${ }^{-}$, and $p<0.05$ compared with $\mathrm{Tpg}^{+}$values in cells expressing Bcl-2. $C$, Mutant PS-1 enhances $\left[\mathrm{Ca}^{2+}\right]_{\mathrm{i}}$ responses to thapsigargin: attenuation by Bcl-2. ${ }^{*} p<0.001$ compared with corresponding values for $\mathrm{Tpg}^{-}, p<0.01$ compared with $\mathrm{Tpg}^{+}$values in cells expressing Bcl-2, and $p<0.01$ compared with Tpg ${ }^{+}-\mathrm{PS}_{1}$ Tet-off values $(B)$; ANOVA with Scheffé's post hoc tests for pair-wise comparisons.

are affected in $\mathrm{AD}$. We found that both undifferentiated and differentiated PC12 cells expressing PS-1 L286V were extremely sensitive to apoptotic cell death when compared with various control cell lines. These findings suggest that the mutated PS-1 protein possesses an adverse proapoptotic property. Overexpression of wild-type PS-1, at levels similar to or greater than mutant PS-1 levels, did not result in increased vulnerability of PC12 cells to apoptosis, indicating that the proapoptotic action of PS-1 L286V was not simply the consequence of increased levels of PS-1 protein. Although the specific nature of that adverse property of the PS-1 mutation was not established in the present study, the data suggest an action on systems that regulate free radical metabolism and/or calcium homeostasis. Thus, levels of cellular peroxides induced by $\mathrm{A} \beta$ were increased greatly in cells expressing the PS-1 mutation, as compared with control lines, and two different antioxidants (vitamin $\mathrm{E}$ and propyl gallate) protected PC12 cells against cell death induced by $\mathrm{A} \beta$. The antioxidants also suppressed $A \beta$-induced increases in intracellular peroxide and calcium levels, consistent with previous data suggesting that the mechanism of $\mathrm{A} \beta$ neurotoxicity involves membrane lipid peroxidation and impairment of membrane ion transport systems and calcium influx (Mattson et al., 1992; Behl et al., 1994; Goodman and Mattson, 1994; Mark et al., 1995, 1997a,b).

Previous studies of mechanisms of neuron death induced by trophic factor withdrawal and $\mathrm{A} \beta$ have implicated reactive oxygen species (ROS) (Hockenbery et al., 1993; Kane et al., 1993; Greenlund et al., 1995). We found that levels of oxidative stress and apoptosis after NGF withdrawal from differentiated PC12 cells were enhanced in cells expressing mutant PS-1, but not in cells overexpressing wild-type PS-1. These effects of mutant PS-1 were not attributable to changes that occurred during the process of cellular differentiation, because we allowed the cells to differentiate before induction of PS-1 expression by using the Tet-off system. Considerable data indicate that levels of oxidative stress are increased in $\mathrm{AD}$ brain, particularly in the environment of neuritic plaques and in neurofibrillary tangles (for review, see
Benzi and Moretti, 1995; Smith et al., 1995); levels of oxidative stress also are increased in the brain during normal aging (Stadtman, 1992). The present findings suggest the possibility that PS-1 mutations may promote oxidative stress and thereby sensitize neurons to decrements in trophic factor support and increased accumulations of $\mathrm{A} \beta$ that occur in the aging brain. The data also may provide at least a partial explanation for the increased production of $\mathrm{A} \beta$ documented in blood and other tissues from human carriers of PS-1 mutations (Scheuner et al., 1996), because studies have shown that manipulations that promote metabolic stress and increase $\left[\mathrm{Ca}^{2+}\right]_{\mathrm{i}}$ in cultured neurons can alter proteolytic processing of $\beta$-amyloid precursor protein ( $\beta$ APP) in cultured cells in favor of increased A $\beta$ production (Gabuzda et al., 1994; Querfurth and Selkoe, 1994).

PS-1 seems to be localized to the ER in several cell types, including neurons (Guo et al., 1996; Kovacs et al., 1996; Walter et al., 1996). Calcium imaging studies of cultured PC12 expressing PS-1 L286V have shown that this mutation alters calcium release from ER stores such that calcium responses to agonists that activate the $\mathrm{IP}_{3}$ pathway (e.g., muscarinic cholinergic agonists and bradykinin) are enhanced greatly (Guo et al., 1996). The perturbed calcium homeostasis observed in PC12 cells expressing mutant PS-1 is consistent with reports that calcium signaling is altered in cultured fibroblasts taken from carriers of PS-1 mutations (McCoy et al., 1993; Ito et al., 1994). Our data suggest that disruption of calcium homeostasis by mutant PS-1 could be linked mechanistically to its proapoptotic action because dantrolene, an agent that blocks calcium release from ER, protected cells against the death-promoting effect of the PS-1 mutation. Recent findings in studies of non-neuronal cells have linked ER calcium regulation to apoptosis. For example, Lam et al. (1993) showed that glucocorticoids induce release of calcium from ER, which is correlated with subsequent DNA fragmentation and apoptosis, and Khan et al. (1996) provided evidence that lymphocyte apoptosis is mediated by increased expression of $\mathrm{IP}_{3}$ receptors. We found that thapsigargin-induced increases of $\left[\mathrm{Ca}^{2+}\right]_{i}$ were enhanced in PC12 cells expressing mutant PS-1 and that Bcl-2 
prevented the enhanced response in cells expressing mutant PS-1. Lam et al. (1994) showed that Bcl-2 protects lymphoma cells against apoptosis induced by thapsigargin and suppresses calcium release from ER. The localization of mutant PS-1 to ER (Guo et al., 1996) suggests that its effects on ER calcium homeostasis and apoptosis may be linked mechanistically, a possibility supported by our data. The ability of dantrolene to suppress the increased peroxide accumulation induced by $\mathrm{A} \beta$ in PC12 cells expressing PS-1 L286V suggests that calcium release from ER contributes to the enhanced oxidative stress associated with mutant PS-1 expression. However, in addition to calcium release from ER, calcium influx through voltage-dependent plasma membrane channels also may be involved, because nifedipine protected cells against $\mathrm{A} \beta$ toxicity and suppressed elevation of $\left[\mathrm{Ca}^{2+}\right]_{i}$ and peroxide accumulation induced by $\mathrm{A} \beta$. These data are consistent with previous studies of primary neurons and PC12 cells showing that removal of extracellular calcium or treatment with nifedipine attenuates $\mathrm{A} \beta$ toxicity (Mattson et al., 1993a; Weiss et al., 1994).

The observation that both antioxidants and calcium channel blockers protected neurons against the adverse effects of the PS-1 mutation are consistent with a scenario in which $\mathrm{A} \beta$ induces a vicious cycle in which oxidative stress disrupts ion homeostasis, which, in turn, promotes further oxidative stress. There is now abundant evidence to support the involvement of such reciprocating cytotoxic cascades in many different neurodegenerative conditions (Mattson et al., 1992; Zhang et al., 1993; Goodman et al., 1996). Thus, although both the normal function of PS-1 and the exact alteration that results from PS-1 mutations are unknown, our data indicate that PS-1 mutations promote neurodegenerative apoptotic cascades involving perturbed ion homeostasis and oxidative stress.

Recent data from studies of brain tissue, blood, and cultured fibroblasts from carriers of PS mutations and studies of transfected cell lines indicate that cells expressing PS mutations produce greater than normal levels of A $\beta 1-42$ (Borchelt et al., 1996; Lemere et al., 1996; Scheuner et al., 1996). In addition, studies of transgenic mice that express mutant PS-1 suggest that levels of A $\beta 1-42$ are increased in brain tissue (Duff et al., 1996). The latter data suggest that PS-1 mutations may cause early onset AD by altering $\beta$ APP processing in ways that lead to increased $\mathrm{A} \beta$ production. The increased vulnerability of neuronal cells expressing PS- 1 L286V to $\mathrm{A} \beta$ toxicity and trophic factor withdrawal documented in the present study is unlikely to result from increased $\mathrm{A} \beta$ production because $\mathrm{PC} 12$ cells are a rat cell line and, in contrast to human $\mathrm{A} \beta$, rat $\mathrm{A} \beta$ is neither amyloidogenic nor neurotoxic (Otvos et al., 1993). However, it is conceivable that altered processing of $\beta$ APP could reduce levels of neuroprotective secreted forms of APP, which have been shown to protect neurons against oxidative apoptotic insults, including $\mathrm{A} \beta$ toxicity and glucose withdrawal (Mattson et al., 1993b; Goodman and Mattson, 1994; Furukawa et al., 1996).

Collectively, our data suggest that mutant PS-1 protein possesses an adverse proapoptotic property. Wolozin et al. (1996) recently reported that PC12 cells overexpressing wild-type PS-2 exhibit increased apoptosis after trophic factor withdrawal and that a PS-2 mutant enhanced basal levels of apoptosis. Deng et al. (1996) reported that overexpression of wild-type PS-2 increased vulnerability of PC12 cells to apoptosis induced by staurosporine or hydrogen peroxide. ALG-3, the mouse homolog of PS-2, was shown to modulate apoptosis in T lymphocytes (Vito et al., 1996), although in the latter case ALG-3 prevented apoptosis. We observed neither increased nor reduced apoptosis in PC12 cells overexpressing wild-type PS-1, suggesting that PS-1 does not function directly in an apoptotic pathway and that mutant PS-1 acquires a novel adverse property. However, we cannot rule out the possibility that mutant PS-1 interferes with a normal trophic property of endogenous PS-1 in a loss-of-function scenario.

\section{REFERENCES}

Bastitatou A, Greene LA (1991) Aurintricarboxylic acid rescues PC12 cells and sympathetic neurons from cell death caused by nerve growth factor deprivation: correlation with suppression of endonuclease activity. J Cell Biol 115:461-471.

Behl C, Davis JB, Lesley R, Schubert D (1994) Hydrogen peroxide mediates amyloid $\beta$-protein toxicity. Cell 77:817-827.

Benzi G, Moretti A (1995) Are reactive oxygen species involved in Alzheimer's disease? Neurobiol Aging 16:661-674.

Black MM, Greene LA (1982) Changes in the colchicine susceptibility of microtubules associated with neurite outgrowth: studies with nerve growth factor-responsive PC12 pheochromocytoma cells. J Cell Biol 95:379-386.

Borchelt DR, Thinakaran G, Eckman CB, Lee MK, Davenport F, Ratovitsky T, Prada C-M, Kim G, Seekins S, Yager D, Slunt HH, Wang R, Seeger M, Levey AI, Gandy SE, Copeland NG, Jenkins NA, Price DL, Younkin SG, Sisodia SS (1996) Familial Alzheimer's disease-linked presenilin-1 variants elevate $\mathrm{A} \beta 1-42 / 1-40$ ratio in vitro and in vivo. Neuron 17:1005-1013.

Bredesen DE (1995) Neural apoptosis. Ann Neurol 38:839-851.

Bruce AJ, Malfroy B, Baudry M (1996) $\beta$-amyloid toxicity in organotypic cultures: protection by EUK-8, a synthetic catalytic free radical scavenger. Proc Natl Acad Sci USA 88:3633-3636.

Ciutat D, Esquerda JE, Caldero J (1995) Evidence for calcium regulation of spinal cord motoneuron death in the chick embryo in vivo. Dev Brain Res 86:167-179.

Cook DB, Sung JC, Golde TE, Felsenstein KM, Wojczyk BS, Tanzi RE, Trojanowski JQ, Lee VMY, Doms RW (1996) Expression and analysis of presenilin-1 in a human neuronal system: localization in cell bodies and dendrites. Proc Natl Acad Sci USA 93:9223-9228.

Cribbs DH, Chen L, Bendle SM, La Ferla FM (1996) Widespread neuronal expression of the presenilin-1 early-onset Alzheimer's disease in the murine brain. Am J Pathol 148:1797-1806.

Deng G, Pike CJ, Cotman CW (1996) Alzheimer-associated presenilin-2 confers increased sensitivity to apoptosis in PC12 cells. FEBS Lett 397:50-54.

Doan A, Thinakaran G, Borchelt DR, Slunt HH, Ratovitsky T, Podlisny M, Selkoe DJ, Seeger M, Gandy SE, Price DL, Sisodia SS (1996) Protein topology of presenilin-1. Neuron 17:1023-1030.

Duff K, Eckman C, Zehr C, Yu X, Prada C-M, Perez-Tur J, Hutton M, Buee L, Harigaya Y, Yager D, Morgan D, Gordon MN, Holcomb L, Refolo L, Zenk B, Hardy J, Younkin S (1996) Increased amyloid$\beta 42(43)$ in brains of mice expressing mutant presenilin-1. Nature 383:710-713.

Elder GA, Tezapsidis N, Carter J, Shioi J, Bouras C, Li D, Johnston JM, Efthimiopoulos S, Friedrich Jr VL, Robakis NK (1996) Identification and neuron-specific expression of the S182/presenilin-1 protein in human and rodent brains. J Neurosci Res 45:308-320.

Forloni G, Chiesa R, Smiroldo S, Verga L (1993) Apoptosis-mediated neurotoxicity induced by chronic application of $\beta$-amyloid fragment 25-35. NeuroReport 4:523-526.

Fukuyama R, Wadhwani KC, Galdzicki Z, Rapoport SI, Ehrenstein G (1994) $\beta$-Amyloid polypeptide increases calcium uptake in PC12 cells: a possible mechanism for its cellular toxicity in Alzheimer's disease. Brain Res 667:269-272.

Furukawa K, Sopher B, Rydel RE, Begley JG, Martin GM, Mattson MP (1996) Increased activity-regulating and neuroprotective efficacy of $\alpha$-secretase-derived secreted APP is conferred by a C-terminal heparinbinding domain. J Neurochem 67:1882-1896.

Gabuzda D, Busciglio J, Chen L, Matsudaira P, Yankner BA (1994) Inhibition of energy metabolism alters the processing of amyloid precursor protein and induces a potentially amyloidogenic derivative. J Biol Chem 269:13623-13628.

Games D, Adams D, Alessandrinl R, Barbour R, Berthelette P, Blackwell C, Carr T, Clemens J, Donaldson T, Gillespie F, Guido T, Hagoplan S, 
Johnson-Wood K, Khan K, Lee M, Lelbowitz E, McConlogue S, Montoya-Zavala M, Mucke L, Paganini L, Penniman E, Power M, Schenk D, Seubert P, Snyder B, Soriano F, Tan H, Vitale J, Wadsworth S, Wolozin B, Zhao J (1995) Alzheimer-type neuropathology in transgenic mice overexpressing V717F $\beta$-amyloid precursor protein. Nature 373:523-527.

Giannakopoulos P, Bouras C, Kovari E, Shioi J, Tezapsidis N, Hof PR, Robakis NK (1997) Presenilin-1 immunoreactive neurons are preserved in late-onset Alzheimer's disease. Am J Pathol 150:429-436.

Goodman Y, Mattson MP (1994) Secreted forms of $\beta$-amyloid precursor protein protect hippocampal neurons against amyloid $\beta$-peptide-induce oxidative injury. Exp Neurol 128:1-12.

Goodman Y, Bruce AJ, Cheng B, Mattson MP (1996) Estrogens attenuate and corticosterone exacerbates excitotoxicity, oxidative injury, and amyloid $\beta$-peptide toxicity in hippocampal neurons. J Neurochem 66:1836-1844.

Greenlund LJ, Deckwerth TL, Johnson EM (1995) Superoxide dismutase delays neuronal apoptosis: a role for reactive oxygen species in programmed neuronal death. Neuron 14:303-315.

Gschwind M, Huber G (1995) Apoptotic cell death induced by $\beta$-amyloid 1-42 peptide is cell type-dependent. J Neurochem 65:292-300.

Guo Q, Furukawa K, Sopher BL, Pham DG, Robinson N, Martin GM, Mattson MP (1996) Alzheimer's PS-1 mutation perturbs calcium homeostasis and sensitizes PC12 cells to death induced by amyloid $\beta$-peptide. NeuroReport 8:379-383.

Hockenbery D, Oltvai ZN, Yin XM, Milliman CL, Korsmeyer SH (1993) Bcl-2 functions in an antioxidant pathway to prevent apoptosis. Cell 75:241-251.

Hsaio K, Chapman P, Nilsen S, Eckman C, Harigaya Y, Younkin S, Yang F, Cole G (1996) Correlative memory deficits, $A \beta$ elevation, and amyloid plaques in transgenic mice. Science 274:99-103.

Ito E, Oka K, Etcheberrigaray R, Nelson TJ, McPhie DL, Tofel-Grehl B, Gibson GE, Alkon DL (1994) Internal $\mathrm{Ca}^{2+}$ mobilization is altered in fibroblasts from patients with Alzheimer disease. Proc Natl Acad Sci USA 91:534-538.

Kane DJ, Sarafian TA, Anton R, Hahn H, Gralla EB, Valentine JS, Ord T, Bredesen DE (1993) Bcl-2 inhibition of neural death: decreased generation of reactive oxygen species. Science 262:1274-1277.

Kovacs DM, Fausett HJ, Page KJ, Kim T-W, Moir RD, Merriam DE, Hollister RD, Hallmark OG, Mancini R, Felsenstein KM, Hyman BT, Tanzi RE, Wasco W (1996) Alzheimer-associated presenilins 1 and 2 : neuronal expression in brain and localization to intracellular membranes in mammalian cells. Nat Med 2:224-229.

Kruman I, Guo Q, Bruce AJ, Bredesen DE, Mattson MP (1996) Hydroxynonenal may mediate apoptotic neuronal death induced by trophic factor withdrawal and oxidative insults. Soc Neurosci Abstr 22:1481.

Lam M, Dubyak G, Distelhorst CW (1993) Effect of glucocorticosteroid treatment on intracellular calcium homeostasis in mouse lymphoma cells. Mol Endocrinol 7:686-693.

Lemere CA, Lopera F, Kosik KS, Lendon CL, Ossa J, Saido TC, Yamaguchi H, Ruiz A, Martinez A, Madrigal L, Hincapie L, Arango JC Anthony DC, Koo EH, Goate AM, Selkoe DJ, Arango VJC (1996) The E280A presenilin-1 Alzheimer mutation produces increased $\mathrm{A} \beta 42$ deposition and severe cerebellar pathology. Nat Med 2:1146-1150.

Levy-Lahad E, Wasco W, Poorkaj P, Romano DM, Oshima J, Pettingell WH, Yu C-E, Jondro PD, Schmidt SD, Wang K, Crowley AC, Fu Y-H, Guenette SY, Galas D, Nemens E, Wijsman EM, Bird TD, Schellenberg GD, Tanzi RE (1995) Candidate gene for the chromosome 1 familial Alzheimer's disease locus. Science 269:973-977.

Li X, Greenwald I (1996) Membrane topology of the C. elegans SEL-12 presenilin. Neuron 17:1015-1021.

Loo DT, Copani A, Pike CJ, Whittemore ER, Walencewicz AJ, Cotman CW (1993) Apoptosis is induced by $\beta$-amyloid in cultured central nervous system neurons. Proc Natl Acad Sci USA 90:7951-7955.

Mark RJ, Hensley K, Butterfield DA, Mattson MP (1995) Amyloid $\beta$-peptide impairs ion-motive ATPase activities: evidence for a role in loss of neuronal $\mathrm{Ca}^{2+}$ homeostasis and cell death. J Neurosci 15:6239-6249.

Mark RJ, Lovell MA, Markesbery WR, Uchida K, Mattson MP (1997a) A role for 4-hydroxynonenal in disruption of ion homeostasis and neuronal death induced by amyloid $\beta$-peptide. J Neurochem 68:255-264.

Mark RJ, Pang Z, Geddes JW, Mattson MP (1997b) Amyloid $\beta$-peptide impairs glucose uptake in hippocampal and cortical neurons: involvement of membrane lipid peroxidation. J Neurosci 17:1046-1054.

Mattson MP, Cheng B, Davis D, Bryant K, Lieberburg I, Rydel RE (1992)
$\beta$-Amyloid peptides destabilize calcium homeostasis and render human cortical neurons vulnerable to excitotoxicity. J Neurosci 12:376-389.

Mattson MP, Tomaselli K, Rydel RE (1993a) Calcium-destabilizing and neurodegenerative effects of aggregated $\beta$-amyloid peptide are attenuated by basic FGF. Brain Res 621:35-49.

Mattson MP, Cheng B, Culwell A, Esch F, Lieberburg I, Rydel RE (1993b) Evidence for excitoprotective and intraneuronal calciumregulating roles for secreted forms of $\beta$-amyloid precursor protein. Neuron 10:243-254.

Mattson MP, Barger SW, Begley JG, Mark RJ (1995) Calcium, free radicals, and excitotoxic neuronal death in primary cell culture. Methods Cell Biol 46:187-216.

McCoy KR, Mullins RD, Newcomb TG, Ng GM, Pavlinkova G, Polinsky RJ, Nee LE, Sisken JE (1993) Serum- and bradykinin-induced calcium transients in familial Alzheimer's fibroblasts. Neurobiol Aging 14:447-455.

Mullan M, Crawford F (1993) Genetic and molecular advances in Alzheimer's disease. Trends Neurosci 16:398-403.

Murphy GM, Forno LS, Ellis WG, Nochlin D, Levy-Lahad E, Poorkaj P, Bird TD, Jiang Z, Cordell B (1996) Antibodies to presenilin proteins detect neurofibrillary tangles in Alzheimer's disease. Am J Pathol 149:1839-1846.

Otvos L, Szendrei GI, Lee VM, Mantsch HH (1993) Human and rodent Alzheimer $\beta$-amyloid peptides acquire distinct conformations in membrane-mimicking solvents. Eur J Biochem 211:249-257.

Prehn JH, Bindokas VP, Marcuccilli CJ, Krajewski S, Reed JC, Miller RJ (1994) Regulation of neuronal $\mathrm{Bcl} 2$ protein expression and calcium homeostasis by transforming growth factor type beta confers wideranging protection on rat hippocampal neurons. Proc Natl Acad Sci USA 91:12599-12603.

Querfurth HW, Selkoe DJ (1994) Calcium ionophore increases amyloid $\beta$-peptide production by cultured cells. Biochemistry 33:4550-4561.

Rabizadeh S, Bitler CM, Butcher LL, Bredesen DE (1994) Expression of the low-affinity nerve growth factor receptor enhances $\beta$-amyloid peptide toxicity. Proc Natl Acad Sci USA 91:10703-10706.

Rogaev EI, Sherrington R, Rogaeva EA, Levesque G, Ikeda M, Liang Y, Chi H, Lin C, Holman K, Tsuda T, Mar L, Sorbi S, Nacmias B, Piacentini S, Amaducci L, Chumakov I, Cohen D, Lannfelt L, Fraser PE, Rommens JM, St. George-Hyslop PH (1995) Familial Alzheimer's disease in kindreds with missense mutations in a gene on chromosome 1 related to the Alzheimer's disease type 3 gene. Nature 376:775-778.

Rukenstein A, Rydel RE, Greene LA (1991) Multiple agents rescue PC12 cells from serum-free cell death by translation- and transcriptionindependent mechanisms. J Neurosci 11:2552-2563.

Scheuner D, Eckman C, Jensen M, Song X, Citron M, Suzuki N, Bird TD, Hardy J, Hutton M, Kukull W, Larson E, Levy-Lahad E, Viitanen M, Peskind E, Poorkaj P, Schellenberg G, Tanzi R, Wasco W, Lannfelt L, Selkoe D, Younkin S (1996) The amyloid $\beta$-protein deposited in the senile plaques of Alzheimer's disease is increased in vivo by the presenilin 1 and 2 and APP mutations linked to familial Alzheimer's disease. Nat Med 2:864-870.

Selkoe DJ (1989) Biochemistry of altered brain proteins in Alzheimer's disease. Annu Rev Neurosci 12:463-490.

Shearman MS, Ragan CI, Iversen LL (1994) Inhibition of PC12 cell redox activity is a specific, early indicator of the mechanism of $\beta$-amyloid-mediated cell death. Proc Natl Acad Sci USA 91:1470-1474.

Sherrington R, Rogaev EI, Liang Y, Rogaeva EA, Levesque G, Ikeda M, Chi H, Lin C, Li G, Holman K, Tsuda T, Mar L, Foncin J-F, Bruni AC, Montesi MP, Sorbi S, Rainero I, Pinessi L, Nee L, Chumakov I, Pollen D, Brookes A, Sansequ P, Polinsky RJ, Wasco W, Da Silva HAR, Haines JL, Pericak-Vance MA, Tanzi RE, Roses AD, Fraser PE, Rommens JM, St. George-Hyslop PH (1995) Cloning of a gene bearing missense mutations in early-onset familial Alzheimer's disease. Nature 375:754-760.

Smale G, Nichols NR, Brady DR (1995) Evidence for apoptotic cell death in Alzheimer's disease. Exp Neurol 133:225-230.

Smith MA, Sayre LM, Monnier VM, Perry G (1995) Radical aging in Alzheimer's disease. Trends Neurosci 18:172-176.

Stadtman E (1992) Protein oxidation and aging. Science 257:1220-1224. Su JH, Anderson AJ, Cummings B, Cotman CW (1994) Immunocytochemical evidence for apoptosis in Alzheimer's disease. NeuroReport 5:2529-2533.

Takei N, Endo Y (1994) $\mathrm{Ca}^{2+}$ ionophore-induced apoptosis on cultured embryonic rat cortical neurons. Brain Res 652:65-70.

Thinakaran G, Borchelt DR, Lee MK, Slunt HH, Spitzer L, Kim G, 
Ratovitsky T, Davenport F, Norstedt C, Seeger M, Hardy J, Levey A, Gandy SE, Jenkins NA, Copeland NG, Price DL, Sisodia SA (1996) Endoproteolysis of presenilin-1 and accumulation of processed derivatives in vivo. Neuron 17:181-190.

Thompson CB (1995) Apoptosis in the pathogenesis and treatment of disease. Science 267:1456-1462.

Vito P, Lacan E, D'Adamio L (1996) Interfering with apoptosis: $\mathrm{Ca}^{2+}$. binding protein ALG-2 and Alzheimer's disease gene ALG-3. Science 271:521-525.

Walter J, Capell A, Grunberg J, Pesold B, Schindzielorz A, Prior R, Podlisny MB, Fraser P, St. George-Hyslop PH, Selkoe DJ, Haass C (1996) The Alzheimer's disease-associated presenilins are differentially phosphorylated proteins located predominantly within the endoplasmic reticulum. Mol Med 2:673-691.

Weiss JH, Pike CJ, Cotman CW (1994) $\mathrm{Ca}^{2+}$ channel blockers attenuate $\beta$-amyloid peptide toxicity to cortical neurons in culture. J Neurochem 62:372-375.

Wolozin B, Iwasaki K, Vito P, Ganjei JK, Lacana E, Sunderland T, Zhao B, Kusiak JW, Wasco W, D'Adamio L (1996) Participation of presenilin-2 in apoptosis: enhanced basal activity conferred by an Alzheimer mutation. Science 274:1710-1713.

Zhang Y, Tatsuno T, Carney J, Mattson MP (1993) Basic FGF, NGF, and IGFs protect hippocampal neurons against iron-induced degeneration. J Cereb Blood Flow Metab 13:378-388. 